\title{
Changes and new features in Neurology
}

\author{
Robert C. Griggs, MD
}

In the 18 months since Neurology moved to Rochester, NY, a number of changes have been made, and more are planned. Neurology will soon be available on-line through the electronic journals collections of Ovid Technologies (available at most institutional medical libraries). The Executive Board of the American Academy of Neurology has approved having the journal on-line for all Academy members and all Neurology subscribers within the next year. Increasingly, correspondence in the Neurology office is handled via e-mail, and reviewers can return their reviews to us by e-mail as well. We are also working to develop the ability to send manuscripts to reviewers electronically.

Expedited publication. We are now able to review and publish high quality priority papers within 10 to 14 weeks of submission. These articles must be in a specific format and must meet high standards; the specific requirements are listed in this issue's "Information for Authors."

Editorial mission. As the official journal of the American Academy of Neurology, we place a major emphasis on meeting the needs and responding to the interests of practicing neurologists. We have expanded the number of Editorials to provide perspective and commentary on important clinical studies, and to provide a clinical framework for basic science papers. We publish the Academy's position papers on various issues of neurological practice and treatment. We are particularly interested in publishing original papers on cost-effectiveness, variations in patterns of practice, quality of life, and other topics in health services research. The Editorial by Robert Holloway and Academy President Steven Ringel in our February 1998 issue highlights our call for papers. $^{1}$

Changes. In 1999, Neurology will increase its publication schedule to 18 issues annually. This will al- low us to print all titles and authors' names on the cover for all published articles, including Brief Communications and Clinical/Scientific Notes. Individual issues will be shorter; we will have no more than a $10 \%$ increase in the number of pages per volume.

The following pages introduce a new feature, "In This Issue," a brief overview prepared by the Editors that highlights topics and articles of interest to our readership.

The Newsletter. With this issue, our new Newsletter editor, Robert J. Joynt, MD, PhD, introduces Neurology's "CPC" (Changes, People, and Comments) Newsletter. Dr. Joynt invites submission of brief news items for this section; please mail these to the Neurology office address.

Editorial policy. A revised "Information for Authors" is published in this issue, and will subsequently be published in the first issue of each new Neurology volume: January and July, annually.

Submissions to the journal. International subscriptions to Neurology continue to increase rapidly, and an ever-increasing proportion of papers published in the journal are from abroad; the acceptance rate for these manuscripts is comparable to those from the United States. In 1997, 1,229 papers were received from 49 foreign countries, constituting $56 \%$ of all submissions.

The cover change in January 1998 was dictated in part by our desire to return the authors' names to the cover, which we have accomplished for fulllength articles. The number of papers submitted to Neurology continues to rise, increasing $11 \%$ in 1997 , and $7 \%$ thus far in 1998.

\section{References}

1. Holloway RG, Jr., Ringel SP. Narrowing the evidence-practice gap: strengthening the link between research and clinical practice. Neurology 1998;50:319-322. 


\title{
Neurology
}

\author{
Changes and new features in Neurology \\ Robert C. Griggs \\ Neurology 1998;51;2 \\ DOI 10.1212/WNL.51.1.2
}

This information is current as of July 1, 1998

Updated Information \& Services

References

Citations

Permissions \& Licensing

Reprints including high resolution figures, can be found at: http://n.neurology.org/content/51/1/2.full

This article cites 1 articles, 1 of which you can access for free at: http://n.neurology.org/content/51/1/2.full\#ref-list-1

This article has been cited by 3 HighWire-hosted articles: http://n.neurology.org/content/51/1/2.full\#\#otherarticles

Information about reproducing this article in parts (figures,tables) or in its entirety can be found online at:

http://www.neurology.org/about/about_the_journal\#permissions

Information about ordering reprints can be found online:

http://n.neurology.org/subscribers/advertise

Neurology ${ }^{\circledR}$ is the official journal of the American Academy of Neurology. Published continuously since 1951, it is now a weekly with 48 issues per year. Copyright . All rights reserved. Print ISSN: 0028-3878. Online ISSN: 1526-632X.

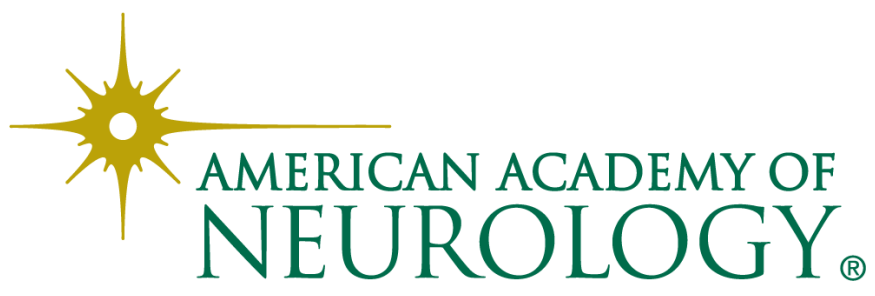

